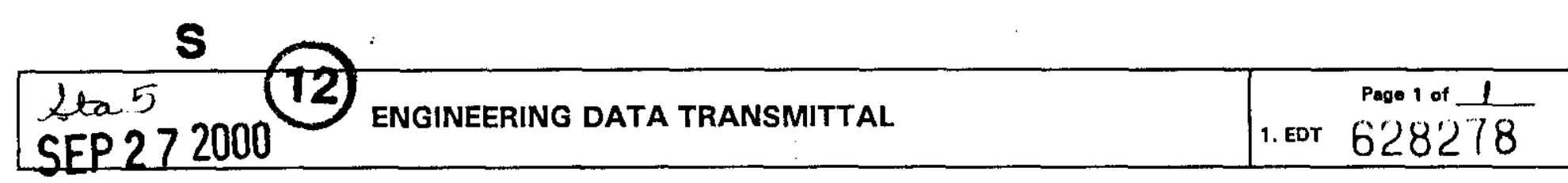

\begin{tabular}{|c|c|}
\hline $\begin{array}{l}\text { 2. To: (Receiving Organization) } \\
\text { Distribution }\end{array}$ & $\begin{array}{l}\text { 3. From: (Originating Organization) } \\
\text { Material Packaging Project }\end{array}$ \\
\hline $\begin{array}{l}\text { 5. Proj./Prog./Dept./Div.: } \\
\text { Bagless Transfer System, 234-5Z }\end{array}$ & $\begin{array}{l}\text { 6. Design Authority/Design Agent/Cgg. Engr.: } \\
\text { T. 4. Larkin }\end{array}$ \\
\hline $\begin{array}{l}\text { 8. Originator Remarks: } \\
\text { This W- } 4 \text { welding Maunel do } \\
\text { requirements of welders and we } \\
\text { welding procedure specifications }\end{array}$ & $\begin{array}{l}\text { nents weld procedures, qualifies } \\
\text { perators, weld inspection, and }\end{array}$ \\
\hline
\end{tabular}

11. Receiver Remarks:

$$
\text { 11A. Design Baseline Document? } \square \text { Yes } \bigotimes \text { No }
$$
4. Related EDT No.:
$\mathrm{n} / \mathrm{a}$
7. Purchase Order No.
$n / a$
9. Equip./Component No.

$\mathrm{n} / \mathrm{a}$

10. System/Bldg./Facility:

234-5Z/PFP

12. Major Assm. Dwg. No.:

$\mathrm{n} / \mathrm{a}$

13. Permit/Permit Application No.:

$\mathrm{n} / \mathrm{a}$

14. Required Response Date: $\mathrm{n} / \mathrm{a}$

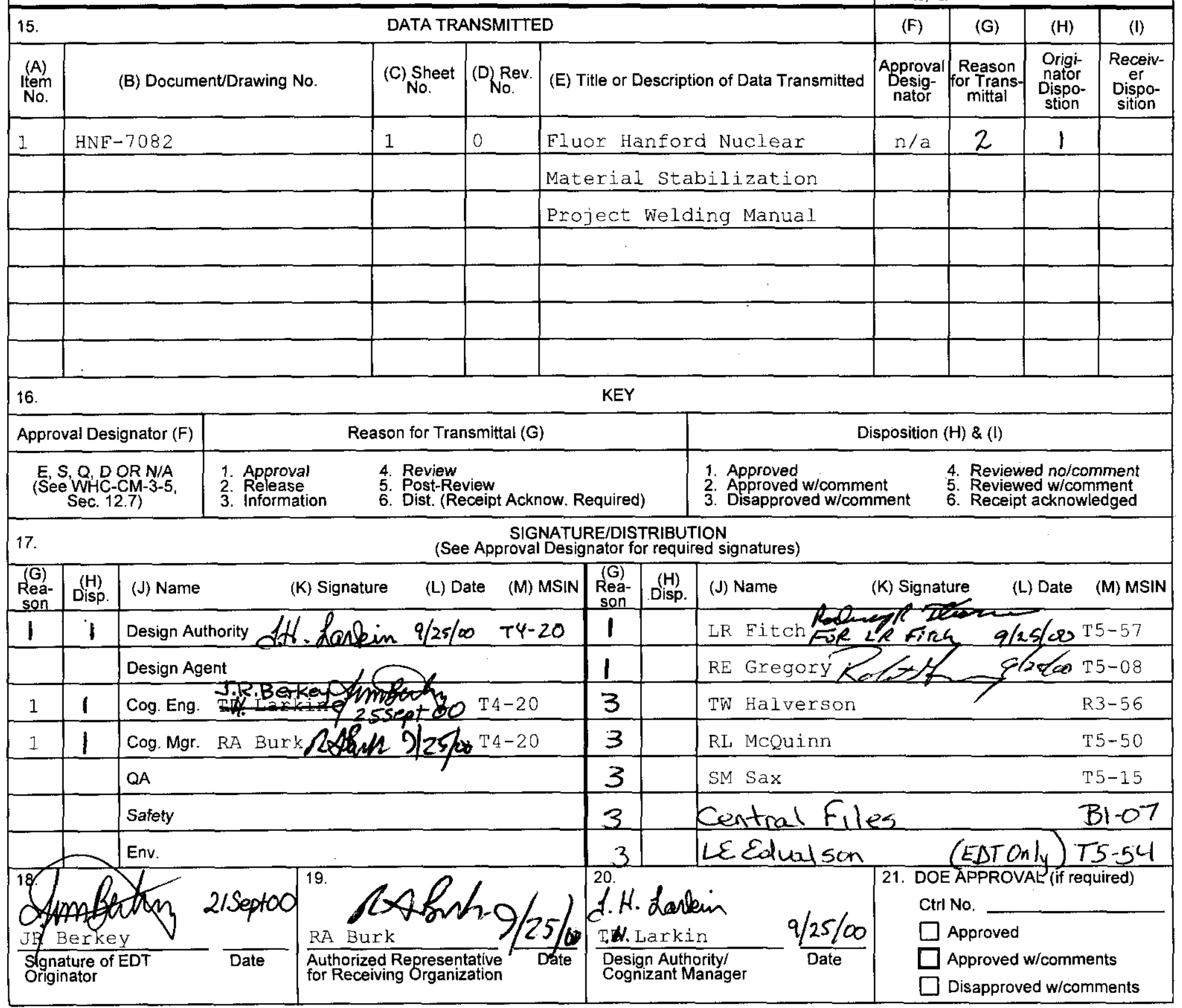


HNF-7082

Revision 0

\section{Fluor Hanford Nuclear Material Stabilization Project Welding Manual}

Prepared for the U.S. Department of Energy

Assistant Secretary for Environmental Management

Project Hanford Management Contractor for the

U.S. Department of Energy under Contract DE-AC06-96RL13200

Fluor Hanford

P.O. Box 1000

Richland, Washington 
HNF-7082

Revision 0

EDT 628278

\section{Fluor Hanford Nuclear Material Stabilization Project Welding Manual}

Document Type: EPRO

Division: NMS

J. R. Berkey

Fluor Hanford

Date Published

September 2000

Prepared for the U.S. Department of Energy

Assistant Secretary for Environmental Management

Project Hanford Management Contractor for the

U.S. Department of Energy under Contract DE-AC06-96RL13200

Fluor Hanford

P.O. Box 1000

Richland, Washington
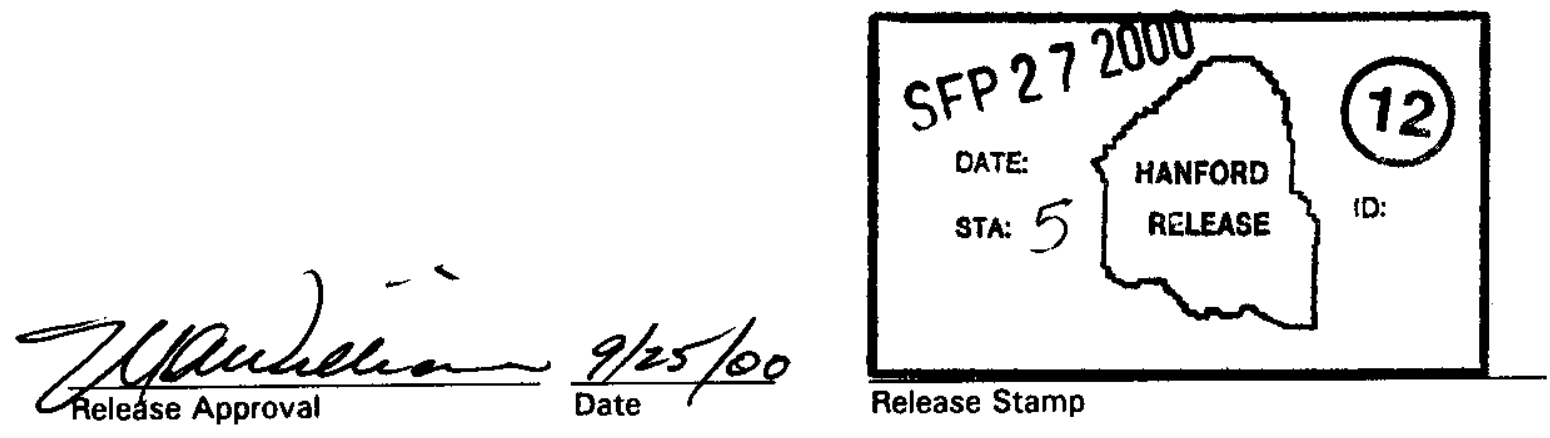

Release Stamp 
HNF-7082

Rev. 0

TRADEMARK DISCLAIMER

Reference herein to any specific commercial product, process,

or service by trade name, trademark, manufacturer, or otherwise, does not necessarily constitute or imply its

endorsement, recommendation, or favoring by the United

States Government or any agency thereof or its contractors or subcontractors.

This report has been reproduced from the best available copy.

Printed in the United States of America

Total Pages: $\quad 28$ 
HNF-7082, Rev 0

Page 1 of 25

\title{
FLUOR HANFORD NUCLEAR MATERIAL STABILIZATION PROJECT WELDING MANUAL
}

\author{
FOREWORD
}

This manual is the property of Fluor Hanford $(\mathrm{FH})$ and is for exclusive use of the company for control of welding activities associated with the W460 Project, in the Plutonium Finishing Plant (PFP) at the U. S. Department of Energy (DOE) Hanford facilities.

The Fluor Hanford Nuclear Material Stabilization Project Welding Manual can only be used by FH. These activities include welder qualifications, production welding, welding filler material control, and postweld heat treatment. Welding Procedure Specifications (WPS) included in this manual are to be used by welders and welding operators qualified to the requirements of this manual.

Additions and revisions to this manual are controlled by Fluor Hanford. Should questions arise as to the applicability of the manual, they should be directed to the Fluor Hanford Welding Engineer (FHWE).

Welding inspection and testing requirements are part of this manual. This manual is comprised of two sections as described below:

General Procedures - This section contains the general procedures for welding on the W460 Project. These general procedures are used with the WPS described in the following section.

In addition, this section contains the procedure to be followed for the qualification of welders and welding operators. All welding personnel selected to use a specific WPS listed in this manual must be currently qualified in accordance with this procedure.

This section also contains the visual weld examination criteria from joint preparation through final acceptance. This criteria is given for each of the canister welds on the W460 Project.

This section also contains the Helium Leak Test Criteria used in testing the BTS and BNFL canister closure welds.

Welding Procedure Specifications - The selected Welding Procedure Specification (WPS) is to be used by the welder or welding operator to make the weld. The selection of the correct WPS is based upon the material to be welded, the engineering specification applicable to the weld, the required filler material, and the desired welding process. Consideration must also be given to the thickness/heat treatment limitations of the WPS to avoid use outside of the qualified ranges. If a WPS that meets the selection criteria is not included in this manual, the FHWE, should be consulted.

If there is any question about appropriate WPS contact FHWE for guidance. 
FLUOR HANFORD WELDING MANUAL

Table of Contents

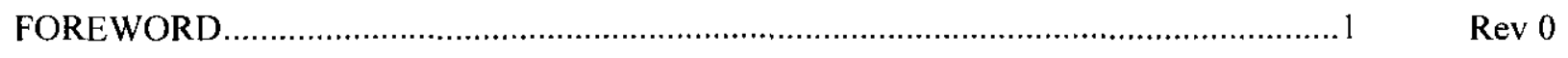

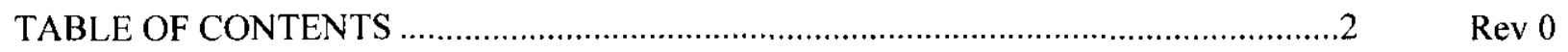

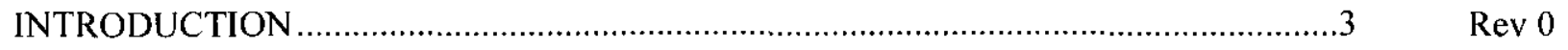

$\begin{array}{lr}\text { GENERAL PROCEDURES } & \text { Rev } 0\end{array}$

Welding Procedure - Welding for W460 Project .......................................................

Qualification of Welders and Welding Operators.....................................................10 Rev 0

Visual Examination of Closure Welds on BTS \& BNFL Canisters ...................................19 Rev 0

Helium Leak Test of Closure Welds on the BTS \& BNFL Canisters

(to be added)

Welding Filler Material Control (to be added)

WELDING PROCEDURE SPECIFICATIONS (WPS) Rev 0

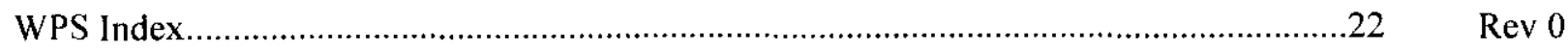

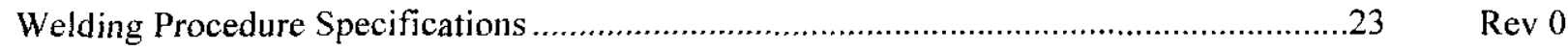


HNF-7082, Rev 0

Page 3 of 25

Introduction

1.0 PURPOSE

The purpose of this section of the welding manual is to:

1. Provide a general description of the major responsibilities of the organizations involved with welding.

2. Provide general guidance concerning the application of codes related to welding.

\subsection{SCOPE}

This manual contains requirements for welding for all Fluor Hanford $(\mathrm{FH})$ welding operators working on the W460 Project, in the Plutonium Finishing Plant (PFP) at the U. S. Department of Energy (DOE) Hanford facilities. These procedures and any additional requirements for these joining processes can be used by all $\mathrm{FH}$ welding operators that are qualified.

The Welding Procedure Specifications (WPS) found in this document were established from Procedure Qualification Records (PQR) qualified by FH specifically for the W460 Project. $P Q R s$ are permanent records of the initial testing and qualification program and are used to backup, and support, the WPS. The identification numbers of the supporting PQR(s) are recorded on each WPS. All PQRs are permanently stored under the supervision of the Fluor Hanford Welding Engineer (FHWE). New PQRs and WPSs will continue to be developed as necessary.

The qualification of welders, welding operators and welding procedures will be performed for FH under supervision and concurrent of the FHWE. All new welding procedures to be entered in this manual or welder personnel to be added to the welder qualification database, shall be approved by the FHWE.

\subsection{RESPONSIBILITIES}

The proper use of the welding procedures found in this manual are the responsibilities of FH.

\subsection{Fluor Hanford Welding Engineer}

The FHWE identifies, obtains and coordinates the services required to qualify welding operators and welding procedures in relation to the W460 welding manual. In addition he has the following exclusive responsibilities.

1. Oversees development and qualification of Welding Procedure Specifications (WPS) and other related joining procedures to be entered in the FH Welding Manual.

2. Prepares and obtains approvals for revisions to the FH Welding Manual.

3. Reviews and approves changes to WPSs that are found in this manual.

4. Retains Procedure Qualification Records (PQR) that support the WPSs found in this welding manual. 
5. Oversees and approves welder performance qualification testing.

6. Maintains the database for welder certification and qualification records.

7. Provides official interpretation of the welding codes as they apply to the W460 Project welding, standards and specifications.

8. When requested, assists and reviews the assignment of welding instructions to work documents for welding of safety class components.

9. Provides assistance with welding related problems to $\mathrm{FH}$ when requested.

\subsection{WELDING PROCEDURE SPECIFICATION (WPS) NUMBERING SYSTEM}

Each WPS is given a unique designation consisting of an alphanumeric notation to assist in providing control over welding document and for reference purposes. Each part of the number system designates something different whether it be the base material, filler material, joining process, or procedure number. The following is an example of a WPS designation.

Note: This numbering system is the same as Fluor Daniel Northwest (FDNW) with the exception of the addition of the filler material designator.

Example: 1-1-1-GT-1, Rev. 0

$$
\begin{aligned}
& 1=\text { Base Material }(\text { Carbon Steel) } \\
& 1=\text { Base Material }(\text { Carbon Steel) } \\
& 1=\text { Filler Material (Carbon Steel) } \\
& \text { GT }=\text { Gas Tungsten Arc Welding Process } \\
& 1=\text { Procedure Number } 1 \\
& \text { Revision }=0
\end{aligned}
$$


WELDING PROCEDURE - Welding for the W460 Project Only

$1.0 \quad$ SCOPE

1.1 This specification is applicable to all welding performed in accordance with the following codes and standards.

1. ASME Section II, "Materials"

2. ASME Section V, "Nondestructive Examination"

3. ASME Section VIII, "Division 1 Pressure Vessels"

4. ASME Section IX, "Welding and Brazing Qualifications"

\subsection{REFERENCES}

2.1 Fluor Hanford Welding Procedure, "Qualification of Welders and Welding Operators for the W460 Project"

2.2 ANSI Z49.1, "Safety in Welding and Cutting"

2.3 OSHA Requirement 1926, Subpart J, Paragraph 350-354, "Welding and Cutting"

\subsection{GENERAL}

3.1 The WPS numbering system follows the format found in the Introduction of this manual in Section 4.0.

3.2 Each WPS indicates the broadest range of qualification for preheat, as welded thickness, and positions.

3.3 All personnel associated with cutting and welding shall conform to the Fluor Hanford (FH) safety program as required by the site Safety Representative.

3.4 Some of the safety provisions for welding and cutting are detailed in Reference 2.2 and 2.3.

\subsection{QUALIFICATIONS AND APPLICATION}

4.1 Welding Procedure Specifications for all code applications used with this Welding Specification are qualified in accordance with ASME Section IX, "Welding and Brazing Qualifications".

4.2 Welding Procedure Specifications for non-code applications shall be qualified as defined by the FHWE.

4.3 If American Welding Society (AWS) standards are referenced, weld procedures qualified per ASME B\&PV Code, Section IX can be used.

4.4 Welders and welding operators shall be qualified and certified in accordance with Reference 2.1. 
4.5 The FHWE is responsible for FH welding procedure qualification testing, preparation of the FH welding procedure specifications, including addenda and revisions, providing technical assistance in welding, and responding to questions related to Codes and Standards being utilized.

Note: GT/gas tungsten arc welding is the only process approved for use at this time. This section is included for possible future use of other welding processes. This note will be removed by the FHWE when any additional welding processes are required.

5.1 Welding processes shall be as specified on the Welding Procedure Specification (WPS). Following is a list of the process designators:

1. $\mathrm{SM}=$ Shielded Metal Arc Welding (SMAW)

2. $\mathrm{GT}=$ Gas Tungsten Arc Welding (GTAW)

3. $\mathrm{GM}=$ Gas Metal Arc Welding (GMAW)

4. $\mathrm{FC}=$ Flux Cored Arc Welding $(\mathrm{FCAW})$

5. $\mathrm{SA}=$ Submerged Arc Welding $(\mathrm{SAW})$

6. $\mathrm{ST}=$ Stud Welding $(\mathrm{SW})$

7. $\mathrm{TB}=$ Torch Brazing

8. GTAA $=$ Gas Tungsten Arc Automatic

5.2 " 1 " through " 8 " above are process designations contained within the WPS number. When more than two sets of letters are designated, the first set of letters indicate the first process to be utilized when making the weld joint.

5.3 Unless otherwise noted on the WPS: SMAW, GTAW, and TB are manual processes; GMAW, FCAW, and SW are semiautomatic processes; and SAW is a machine process; and no processes utilize pulsed current unless noted on the applicable WPS.

Note: Only P8 materials are approved at this time. This section is included for possible future use of additional materials. This note will be removed by the FHWE when any other base materials are required.

6.1 Base materials shall be as listed in the ASME B\&PV Codes Section II \& Section IX.

6.2 Base materials that are not listed in ASME Section II, ASME Section IX, the applicable code, or standard, a P-Number for identification purposes shall be assigned by the Welding Engineer.

6.3 The numbers preceding the letters (paragraph 5.2) in the WPS designation define the Pnumbers that may be joined by welding.

6.4 Base material thicknesses qualified are in accordance with applicable code or standard and are listed on the Welding Procedure Specification (WPS). 
Note: Only autogenous (no filler material added) welds are approved at this time. This Section is included for possible future use of filler materials. This note will be removed by the FHWE when filler materials are required.

7.1 Storage, handling, issuance and control shall be in accordance with procedures developed in accordance with the filler material control portion (to be added when required) of this manual.

7.2 All welding consumables, i.e., covered electrodes, bare wire, flux, flux cored wire, and consumable inserts, shall conform to the requirements of ASME Section II Part C.

7.3 Grouping of electrodes and welding rods for qualification (F-Number) is as defined in ASME B\&PV Code Section VI and Section IX.

8.1 The joint design shall be as required by the applicable drawings or job specifications. If not specified in the design/engineering drawings, the joint design shall be as specified in the WPS.

9.1 Shielding/purging gas type, composition, and flow rate shall be as specified on the WPS.

9.2 Shielding/purging gas shall be welding grade quality unless otherwise required by the WPS.

9.3 Purging of the canister with helium shall be as is specified on the appropriate task instructions. The area shall be evacuated to a partial vacuum and backfilled with helium 3 times prior to placing lid in place and tack welding then welding.

\subsection{POSITION}

10.1 Welding may be performed only in those positions specified by the WPS.

10.2 All BTS and BNFL canister closure welding shall be performed in the $2 \mathrm{G}$ welding position.

\subsection{ELECTRICAL CHARACTERISTICS}

11.1 The electrical characteristics shall be as shown on the applicable welding procedure specification.

11.2 Grounding cables shall be attached through the welding station mechanism. The welding operator will not attach this cable for the BTS or BNFL canister closure welds.

11.3 All welding shall be with single electrodes. 
12.1 Regardless of the method of joint preparation used, the welding groove surfaces shall be reasonably smooth, sound metal, free of slag, scale and oxides.

12.2 The joint preparation and adjacent base metal surfaces shall be cleaned for one inch from each edge of the joint for ferrous material. The joint shall be free of grease, oil, rust, dirt, paint, lacquer, or other materials, which may be detrimental to the weld. Cleaning may be accomplished by wire brushing, filing, grinding with rubber or resin bonded alumina or silicon carbide grinding wheels, chipping, burring with a carbide tools, or by an approved solvent cleaner (as appropriate). Brushes and grinding wheels shall not have been used on other materials when preparing or cleaning one of the following: P8, P2X, P3X, P4X, P5X, P6X.

\subsection{FIT-UP, TACK WELDING, AND TEMPORARY ATTACHMENT WELDS}

13.1 Fit-up shall be accomplished using the lid placement tooling.

13.2 Tack welding shall be accomplished the automatic sequencing in the welding controller.

13.3 Tack welds shall be made in accordance with the WPS by qualified welding operators.

\subsection{PREHEAT}

14.1 Preheat and interpass temperatures shall be as stated on the WPS. In the case of the BTS and $\mathrm{BNFL}$ canisters preheat is $50^{\circ} \mathrm{F}$ and interpass is $350^{\circ} \mathrm{F}$.

14.2 Preheat shall be checked by use of temperature indicating crayons, thermocouple pyrometers, or other approved methods to assure that the required preheat and interpass temperature is maintained. Preheat shall be verified a minimum of 1 inch from the weld bevel.

14.3 In the case of the BTS and BNFL canisters historical data on the room temperature may be used for preheat verification.

14.4 If BTS or BNFL canisters use a 2 pass weld, verification of interpass temperature shall need to be performed. It is recommended to use pyrometers in lieu of temperature indicating crayons.

\subsection{POSTWELD HEAT TREATMENT}

15.1 BTS or BNFL postweid heat treatment is not permitted on any BTS or BNFL canister closure welds.

\subsection{WELDING TECHNIQUE}

16.1 Welding technique is preprogrammed in the welding controller and is not adjustable by the welding operator. 
16.2 The canister lids will be tack welded in three locations at the $0^{\circ}, 90^{\circ}$, and $180^{\circ}$ locations and welding will start at the $270^{\circ}$ location.

16.3 The welding will be pulsed between a high and low value and forward motion of the welding electrode is on the high value.

16.4 The welding current will ramp up and ramp down at the start and finish of the weld.

16.5 The welding operation (excluding the ramp up and ramp down) will be for approximately $374^{\circ}$ of the circumference.

16.6 Peening is not permitted.

\subsection{INTERPASS CLEANING}

17.1 Not required because this weld is a single pass weld.

\subsection{WELD REPAIR}

18.1 Not allowed on BTS and BNFL canister closure welds.

19.0 NOTCH TOUGHNESS/CHARPY IMPACT REQUIREMENTS

Not required on BTS or BNFL canister closure welds.

WELDER AND WELD IDENTIFICATION MARKING

20.1 Welding operator identification marking on the BTS and BNFL canisters is not required and is not allowed.

20.2 All welding operators performing a welding operation on the BTS canister and BNFL canister closure weld shall fill out all appropriate paperwork for traceability on the operators working on each canister. 
WELDING PROCEDURE - Qualification Of Welders And Welding Operators

$1.0 \quad$ SCOPE

1.1 This procedure is applicable to welder and welding operator performance qualification testing in accordance with ASME Section IX and for non code applications as directed by the FHWE.

\subsection{REFERENCES}

2.1 ASME Section IX, "Welding and Brazing Qualifications"

\subsection{DEFINITIONS}

3.1 Welder - One who performs a manual or semi-automatic welding operation.

3.2 Welding Operator - One who operates machine or automatic welding equipment.

3.3 Weld Test Supervisor - The individual authorized by the Fluor Hanford Welding Engineer, who by appropriate training, experience, and assigned responsibility shall conduct the performance qualification testing described herein.

3.4 Fluor Hanford Welding Engineer (FHWE). The FHWE that has appropriate training, experience, and assigned responsibility shall approve the completed qualification test records.

3.5 Manual Welding - Welding wherein the entire welding operation is performed and controlled by hand. This includes all Welding Procedure Specifications (WPS's) stating "Gas Tungsten Arc Welding" and "Shielded Metal Arc Welding" where manual, machine, or automatic is not specifically stated in the title.

3.6 Machine Welding - Welding with equipment which performs the welding operation under the constant observation and control of a welding operator. This includes all WPS's stating "Submerged Arc Welding" and "Machine Gas Tungsten Arc Welding".

3.7 Semi-automatic Arc Welding - Welding with equipment which performs the welding operation under the constant observation and control of a welding operator. This includes all WPS's stating "Submerged Arc Welding" and "Machine Gas tungsten Arc Welding".

3.8 Automatic Welding - Welding with equipment which performs the welding operation without adjustment of the controls after arc initiation by a welding operator. This includes all WPS's stating "Gas Tungsten Arc Automatic (GTAA)".

\subsection{GENERAL}

4.1 The requirements of this procedure shall be administered by the FHWE. 
4.2 All welders and welding operators shall be qualified in accordance with applicable codes and specification requirements prior to joining on production work.

4.3 Welders and welding operators who satisfactorily complete the qualification requirements of American Society of Mechanical Engineers (ASME) Section IX shall be considered qualified to join metallic piping, pressure and nonpressure retaining components, and appurtenances under the provision of ASME within the limitations of the qualification.

4.4 Welders who satisfactorily complete the qualification requirements identified by an American Welding Society (AWS) code shall be considered qualified to weld under the provisions of the applicable code within the limitations of the qualification.

4.5 With prior engineering (design) approval, welders qualified in accordance with ASME section IX may be utilized when specifications require welding in accordance with AWS standards.

4.6 Welders who have been qualified by companies other than FH may be certified by the FHWE to weld under the provisions of ASME and/or the AWS codes, provided the requirements stipulated by these codes are met.

4.7 Prior to testing, the welder/welding operator shall be instructed on the specific WPS and advised of the visual examination criteria of the specified weld.

4.8 Each qualified welding operator on the W460 project will use his or her assigned HID and/or payroll number as a personal identification number.

4.9 A welder or welding operator shall be qualified by making tests with each individual welding process on separate test coupons.

4.10 The performance test may be terminated at any stage of the testing procedure when it becomes apparent to the test supervisor conducting the tests that the welder or welding operator does not have the required skill to produce satisfactory results.

4.11 All W460 project qualifications shall be performed in the $2 \mathrm{G}$ position unless otherwise specified in the applicable WPS.

4.12 Bend testing or radiography may be utilized for AWS D1.1 and ASME Section IX, however radiography is preferred where the production welds will be radiographed. An exception requires that bend testing be utilized for the GMAW (short arc) process. Bend testing is also required for P No. $2 \mathrm{X}$ and $5 \mathrm{X}$ materials where the GTAW process is not utilized. AWS D9/1 requires visual examination only.

4.13 It is permissible to order coupons for testing and have the test bends or radiograph performed by others.

4.14 In any given production weldment, welders may not deposit a thickness greater than that designated by the Test supervisor for each welding process for which they are to be qualified. 
5.1 The test WPS shall be selected based on the anticipated WPS's to be used in production. This shall include welding processes, joint thicknesses and diameters to be welded.

5.2 The test WPS shall be made available to the welder/welding operator.

6.1 Test coupon material selection shall be in accordance with the applicable code for code welds and as directed by the FHWE for non-code applications.

6.2 Coupon diameter selection shall be based on the ranges to be qualified as permitted in the applicable code.

6.3 Coupon thickness selection shall be based on the thickness ranges to be qualified as permitted in the applicable code. Optimum coupon thickness shall be selected to minimize the number of test and testing time.

6.4 Test joint design for ASME Section IX qualification shall be in accordance with the test WPS, or an optional joint as permitted by the FHWE. The joint design may also be as required by project specifications.

6.5 For ASME Section IX radiographic examination, the minimum weld length to be examined shall be 6 inches and shall include the entire weld circumference for pipe/tube. For small diameter tests, multiple coupons may be required but the number need not exceed four consecutively made test coupons.

\subsection{TEST COUPON IDENTIFICATION}

7.1 Each test coupon to be welded shall be identified with the welder/welding operator's initials, the date testing was initiated, and the test WPS number. This information may be documented in e-mail, letter, etc. to notify the testing laboratory of this testing information on each test coupon.

\subsection{IN PROCESS TESTING REQUIREMENTS}

8.1 Tack welds on pipe/tube may be made in the $2 \mathrm{G}$ position. Tack weld on plate or sheet metal may be made in the $1 \mathrm{G}$ position. The test supervisor may reject tacked coupons for excessive tack length. Bridge tacks or spacers in lieu of tacks are not allowed.

8.2 Tack welds shall be made with the same process to be used for the root pass.

8.3 Tack welds, and starts and stops in the root shall be feathered and shall meet the visual examination requirements of Appendix 2. This step is normally not performed with the automatic sequencing of GTAA.

8.4 After completion of the root pass for ASME Section IX and AWS D1.1, it shall be visually examined to the requirements of Appendix 2. 
8.5 After the weld joint is completely welded it shall be visually examined to the requirement of Appendix 2 prior to any grinding.

8.6 Only the weld cap may be ground for removal of acceptable irregularities, which may inhibit radiographic interpretation. Grinding shall be per the instructions of the Test Supervisor.

9.1 For ASME Section IX test coupon, the acceptance criteria shall be in accordance with ASME Section IX paragraph QW-191.2.

9.2 A radiographic examination report shall be supplied by the radiographer referencing the applicable requirement of "ASME Section IX, QW-191.2".

10.1 Bend test specimens shall be removed and prepared in accordance with the applicable code. The number of specimens removed shall be in accordance with the applicable code and is based on position tested and whether plate or pipe.

10.2 The dimensions of the bend test fixture shall be in accordance with ASME Section IX for code applications. For non-code applications these dimensions shall be as directed by the FHWE.

10.3 Bend test fixture shoulders may be greased. The specimen shall be forced into the die until the curvature of the specimen is such that a $1 / 8$-inch diameter wire cannot be inserted between the specimen and the die.

10.4 For ASME Section IX and non-code applications the weld and heat affected zone shall be completely within the bent portion of the specimen after testing.

10.4.1 The guided-bend specimens shall have no open defects in the weld or heat affected zone exceeding 1/8 inch measure in any direction on the convex surface of the specimen after bending. Cracks occurring on the corners of the specimen during testing shall not be considered unless there is definite evidence that they result from slag inclusion or other internal defects.

\section{$11.0 \quad$ RETESTS}

11.1 A welder or welding operator who fails the prescribed test, may with the approval of the FHWE, be given additional training and subsequently retested.

11.2 If the test failed was by radiographic examination, it is not permissible to perform a bend test on the same coupon subsequent to the RT.

11.3 The welder/welding operator need only be retested for the failed positions. 
12.1 For ASME Section IX and non code application tests the performance qualifications of a welder or welding operator shall be affected under the following conditions.

12.1.1 When he has not welded with a process during a period of 6 months or more, his qualifications for the process shall be expired.

12.1.2 When there is a specific reason to question the welders/welding operator's ability to make acceptable welds, the qualifications which support the welding being performed shall be revoked.

12.2 Renewal of machine and automatic processes shall be in accordance with the original test.

13.1 Exhibit A "Welder Performance Qualification Record", or equivalent form, shall be utilized for the documentation of all testing, passed, or failed, and renewals of welders/welding operators. This information shall be maintained by the FHWE and stored in the welders file.

13.2 Exhibit B "Welders Process Application Record Sheet" shall be completed every month and forwarded to the FHWE. The FHWE shall log the information in the Welder Database and insert the record sheet in the individual welders welder file. The welder/welding operators supervisor shall fill out the Welders Process Application Record Sheet.

13.3 A list of qualified weiders with their limits of qualification shall be made available to foremen, supervisors, quality representatives, and others as necessary to permit accurate assignment of welding operators.

14.0 EXHIBITS AND APPENDICES

14.1 Exhibit A - "Welder Performance Qualification Record"

14.2 Exhibit B - "Welders Process Application Record Sheet"

14.3 Appendix 1- "Welder/Welding Operator Test Instructions"

14.4 Appendix 2 - "Test Coupon Visual Welding Examination Criteria" 
HNF-7082, Rev 0

Exhibit A - "Welder Performance Qualification Record"

Fluor Hanford

Welder Performance Qualifications Record

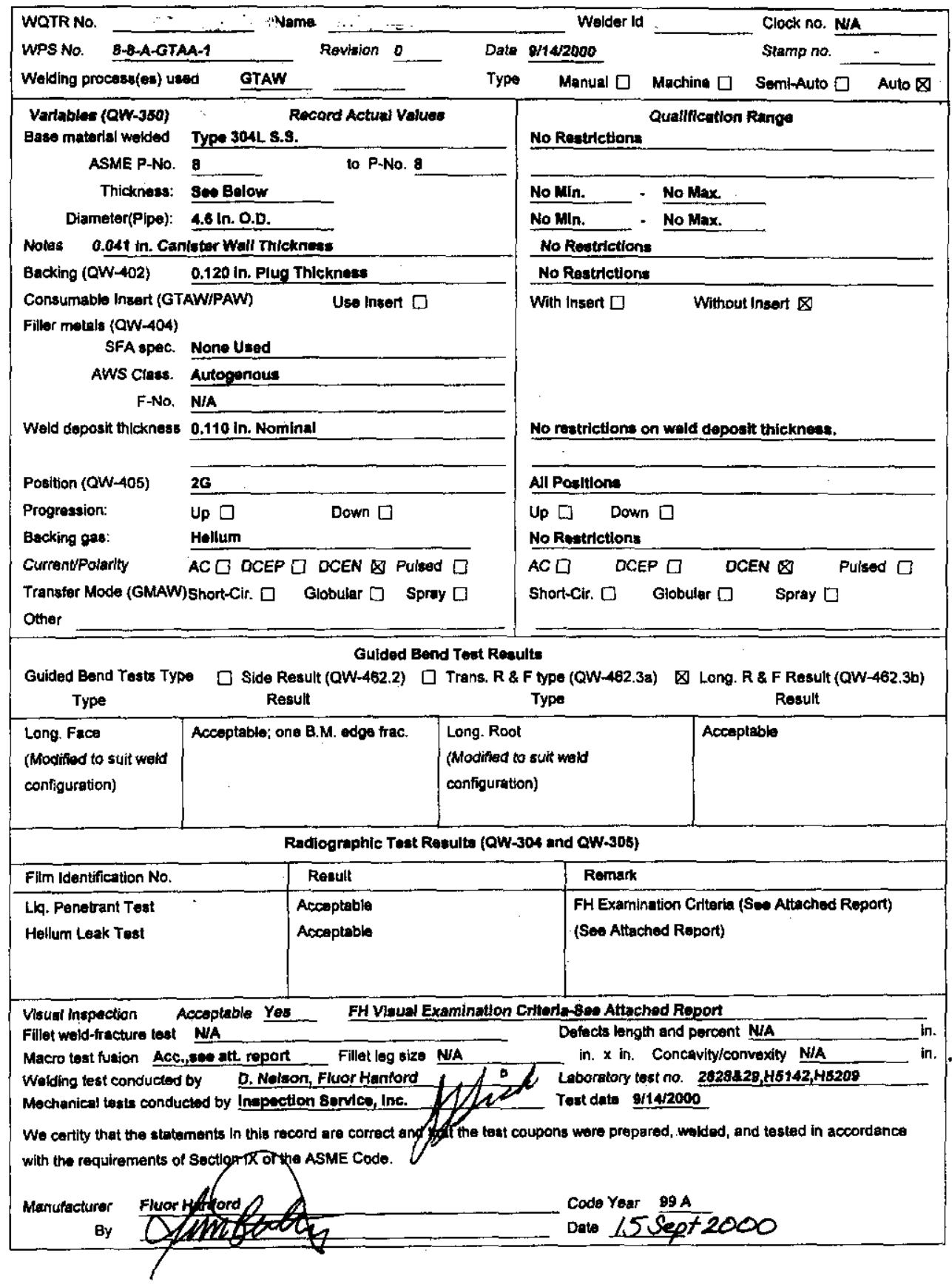


Exhibit B - "Welders/Welding Operators Process Application Record Sheet

\begin{tabular}{|c|c|c|c|c|c|c|c|c|c|c|c|c|c|c|c|c|}
\hline \multicolumn{17}{|c|}{ Fluor Hanford } \\
\hline \multicolumn{17}{|c|}{ Welders/Welding Operators Process Application Record Sheet } \\
\hline \multicolumn{3}{|l|}{ Name: } & \multicolumn{4}{|c|}{ Pay No. } & \multicolumn{4}{|c|}{ Stamp No. } & \multicolumn{6}{|c|}{ Period Ending: } \\
\hline \multicolumn{7}{|c|}{ Contractor Name: Fluor Hanford } & \multicolumn{10}{|c|}{$\begin{array}{l}\text { Return Sheet First of Each Month to Fluor } \\
\text { Hanford Welding Engineer }\end{array}$} \\
\hline $\begin{array}{l}\text { Welding } \\
\text { Process Used }\end{array}$ & \multicolumn{16}{|c|}{ Day of Month } \\
\hline \multirow[t]{8}{*}{ GTAW Automatic } & 1 & $\frac{34}{1}$ & 1 & $\frac{7 / 8}{1}$ & $\frac{910}{7}$ & 1 & $\frac{1+1 / 4}{1}$ & 1 & $\frac{17118}{1}$ & $1 /$ & $\frac{21 / 22}{1}$ & $\frac{27 / 24}{1}$ & $\frac{25 / 26}{1}$ & $\frac{27 / 2}{1}$ & / & $\frac{13}{1}$ \\
\hline & / & 1 & $/$ & / & / & $/$ & 1 & / & 7 & 1 & 1 & 1 & 1 & 1 & 7 & 7 \\
\hline & 1 & 1 & 7 & 7 & 7 & 1 & 1 & 1 & 1 & 1 & 1 & I & 1 & 1 & 1 & 7 \\
\hline & 1 & 7 & 7 & 1 & 7 & 7 & 1 & 7 & 7 & 7 & 7 & 7 & 7 & 7 & 7 & 7 \\
\hline & 1 & 1 & 1 & 1 & 7 & 1 & 1 & 1 & 1 & 1 & 1 & 1 & 1 & 1 & 7 & 7 \\
\hline & 1 & 1 & 1 & 1 & 1 & 1 & 1 & 1 & 1 & 1 & 1 & 1 & 1 & 7 & 7 & 7 \\
\hline & 1 & 7 & 1 & 1 & 7 & 1 & 1 & $T$ & $\pi$ & 7 & 7 & 7 & 7 & 7 & 7 & 7 \\
\hline & 7 & 7 & 7 & 7 & 7 & 7 & 1 & 1 & 1 & 1 & 7 & 1 & 1 & $/$ & 1 & 7 \\
\hline
\end{tabular}

Contract/Job No.

(A) -5 Canister

(B) ZB Canister

(C) BNFL Canister (D)

(E) (F)

Signature of Supervisor

Instruction for Completion/Submittal

Welders Process Application Record Sheet

The welder's supervisor completes the welders process application record sheet and forwards the completed sheet to Fluor Hanford Welding Engineer.

If a welder's process application sheet does not show use of a specific welding process for 6 months, the welder will lose that qualification. If no process application sheet is received for a welder for 6 months, all qualifications will have expired. In either case, requalification is required.

1. Complete the welder identification information requested, one sheet is required for each assigned welder.

2. Enter the contract/job no's worked during the period covered. If welding was performed for "practice", fabrication of "shop aids", or "training" make the appropriate entry in lieu of a contract/job no.

3. Enter the contract/job no. letter of designation (A., B, C, etc.) in the applicable day column for the specific process used on that date.

4. Supervisor/Manager sign in the space provided. 


\section{Appendix 1 - "Welder/Welding Operator Test Instructions"}

1. All welding tests shall be performed on the same equipment as used in production welds.

2. The testing shall be observed by the FHWE or designee.

3. The operation of the test shop and conduct of each performance test is the responsibility of the FHWE or designee.

4. Once the coupon is mounted it shall not be removed from the weld station until so instructed by the Test Supervisor.

5. There shall be no instructions (look in) given to the welding operator during the progress of the test.

6. The Test Supervisor shall perform visual inspection after completion of the complete weld.

7. The welder/welding operator shall read and understand the WPS and adhere to the parameters.

8. The Test Supervisor and/or FH Welding Engineer shall inspect the bend test specimens. The entire weld and heat-affected zone in the bend specimen shall be contained within the bent portion of the strap.

9. The welder shall be advised of any time limits prior to testing by the Test Supervisor.

10. Upon completion of welding the FHWE or designee will process the test weldment for testing and documentation of these results. 
Appendix 2 - "Test Coupon Visual Welding Examination Criteria"

\subsection{Inspection Criteria for BTS Closure Welds}

1. Weld Height (after cut) $=$ or $>6 / 32$ "

2. Weld contour shall be slightly concave with no indications of bulges or areas of convexity.

3. Weld bead shall have a uniform and smooth appearance with even bead ripples.

4. Weld color shall be a golden brown in the weld area with some darkening toward black in the base metal outside the toes of the welds. Areas where tack welds were placed may have a distinctive discoloration in the base metal along the toes of the weld; these areas may be blue/black in color.

5. Surface slag particles are acceptable and are usually $\sim 1 / 32$ " in diameter. If slag appears to cover an unacceptable weld area the slag may be removed with the use of a small grinder to facilitate evaluation of the area. Removal of slag and examination shall be done under the direction of Welding Engineer.

6. No porosity.

7. No cracks.

8. Any indications other than the normal slag particles/islands are rejectable.

9. There shall be no undercut or overlap.

1.2 Inspection criteria for BTS closure weld "Cut Edge"

1. The cut edge shall be free of cracks or open crevices (lack of fusion).

2. The cut edge shall be free of voids or porosity.

3. Any visible indication other than normal "smearing" of the cut edge is cause for rejection. Normal "smearing" of the cut edge is expected and is acceptable.

\subsection{BNFL CANISTER}

\subsection{Inspection Criteria for BNFL Canister}

1. Weld contour shall be flat to slightly convex with no indications of bulges or areas of concavity.

2. Weld head shall have a uniform and smooth appearance with even bead ripples.

3. Weld color shall be a golden brown in the weld area with some darkening toward black in the base metal outside the toes of the welds. Areas where tack welds were placed may have a distinctive discoloration in the base metal along the toes of the weld; these areas may be blue/black in color.

4. Surface slag particles are acceptable and are usually $\sim 1 / 32$ " in diameter. If slag appears to cover an unacceptable weld area the slag may be removed with the use of a small grinder to facilitate evaluation of the area. Removed of slag and examination shall be done under the direction of Welding Engineer.

5. No porosity.

6. No cracks.

7. Any indications other than the normal slag particles/islands are rejectable.

8. There shall be no undercut or overlap.

9. There shall be no erosion of the top corner of the canister. 
$1.0 \quad$ SCOPE

1.1 This procedure provides the guidelines of performing visual examinations on the final closure welds on BTS and BNFL canisters.

\section{$2.0 \quad$ REFERENCES}

2.1 ASNT, SNT-TC-IA, "Recommended Practice for Nondestructive Testing Personnel Qualification and Certification.

2.2 AWS, QCI Standard for AWS Certification of Welding Inspectors.

2.3 DOE-STD-3013-99, "Stabilization, Packaging, and Storage of Plutonium-Bearing Materials".

\subsection{PERSONNEL}

3.1 Personnel performing visual examinations to this procedure shall be currently qualified as an NDE Level II or II or be currently qualified as an AWS CWI.

\subsection{GENERAL REQUIREMENTS}

\subsection{Direct Visual Examination}

4.1.1 Direct visual examination may be made when access is sufficient to place the eye within 24 inches of the surface to be examined and at an angle not less than $30^{\circ}$ to the surface to be examined. Mirrors may be used to improve the angle of vision, and aids such as a magnifying lens may be used to assist examinations. The canister being examined shall be illuminated, if necessary with a flashlight or other auxiliary lighting, to attain a minimum of $15 \mathrm{fc}$ for general examination and a minimum of $50 \mathrm{fc}$ for the detection or study of small discontinuities.

\subsection{Remote Visual Examination}

4.2.1 In some cases, remote visual examination may have to be substituted for direct examination, Remote visual examination may use visual aids such as mirrors, telescopes, borescopes, fiber optics, cameras, or other suitable instruments. Such systems shall have a resolution capability at least equivalent to that obtainable by direct visual observation.

\subsection{Visual Examination of Base Materials}

4.3.1 Minimum visual examination shall include the following items.

a. Proper identification of the item.

b. Dimensions, tolerances, and configuration 
c. Surface condition: corrosion, erosion, scale, cracks, laps, cold shunts, machined surfaces, all where applicable.

d. Edge condition: laminations, segregations, porosity.

e. Evidence of mishandling.

f. Proper item documentation.

\subsection{Visual Examination of Weldments}

4.4.1 Welds shall be visually examined on the outside and inside surface, where readily accessible for compliance with the appropriate acceptance criteria in Section 5.0 of this procedure. Minimum visual examination of welds shall include the following:
a. Contour and finish
b. Surface cracks
c. Undercutting
d. Overlap
e. Surface porosity
f. Excessive reinforcement
g. Excessive underfill
h. Misalignment
i. Incomplete penetration
j. Excessive spatter
k. Excessive arc stricks
1. Excessive grinding or other thickness reductions

\subsection{Weld Acceptance Criteria}

Note: BTS canister shall not have burr cover installed during inspection.

\subsection{BTS CANISTER}

\subsubsection{Inspection Criteria for BTS Canister Closure Welds}

1. Weld Height (after cut) $=$ or $>6 / 32 "$

2. Weld contour shall be slightly concave with no indications of bulges or areas of convexity.

3. Weld bead shall have a uniform and smooth appearance with even bead ripples.

4. Weld color shall be a golden brown in the weld area with some darkening toward black in the base metal outside the toes of the welds. Areas where tack welds were placed may have a distinctive discoloration in the base metal along the toes of the weld; these areas may be blue/black in color.

5. Surface slag particles are acceptable and are usually $\sim 1 / 32$ " in diameter. If slag appears to cover an unacceptable weld area the slag may be removed with the use of a small grinder to facilitate evaluation of the area. Removal of slag and examination shall be done under the direction of Welding Engineer.

6. No porosity.

7. No cracks. 
8. Any indications other than the normal slag particles/islands are rejectable.

9. There shall be no undercut or overlap.

\subsubsection{Inspection criteria for BTS closure weld "Cut Edge"}

1. The cut edge shall be free of cracks or open crevices (lack of fusion).

2. The cut edge shall be free of voids or porosity.

3. Any visible indication other than normal "smearing" of the cut edge is cause for rejection. Normal "smearing" of the cut edge is expected and is acceptable.

\subsection{BNFL CANISTER}

\subsubsection{Inspection Criteria for BNFL Canister}

1. Weld contour shall be flat to slightly convex with no indications of bulges or areas of concavity.

2. Weld bead shall have a uniform and smooth appearance with even bead ripples.

3. Weld color shall be a golden brown in the weld area with some darkening toward black in the base metal outside the toes of the welds. Areas where tack welds were placed may have a distinctive discoloration in the base metal along the toes of the weld; these areas may be blue/black in color.

4. Surface slag particles are acceptable and are usually $\sim 1 / 32$ " in diameter. If slag appears to cover an unacceptable weld area the slag may be removed with the use of a small grinder to facilitate evaluation of the area. Removed of slag and examination shall be done under the direction of Welding Engineer.

5. No porosity.

6. No cracks.

7. Any indications other than the normal slag particles/islands are rejectable.

8. There shall be no undercut or overlap.

9. There shall be no erosion of the top corner of the canister. 


\section{WELDING PROCEDURE SPECIFICATION (WPS) INDEX}

\begin{tabular}{|l|c|l|l|}
\hline \multicolumn{1}{|c|}{ Welding Procedure } & \multicolumn{1}{|c|}{ Revision No. } & \multicolumn{1}{c|}{ Status } \\
\hline 8-8-A-GTAA-1 & 0 & GTAW of BTS-5 & in use \\
\hline 8-8-A-GTAA-2 & 0 & GTAW of BTS-ZB & in development \\
\hline 8-8-A-GTAA-3 & 0 & $\begin{array}{l}\text { GTAW of BNFL } \\
\text { Canister }\end{array}$ & in development \\
\hline & & & \\
\hline
\end{tabular}


HNF-7082, Rev 0 Page 23 of 25

Fluor Hanford

Welding Procedure gpecification

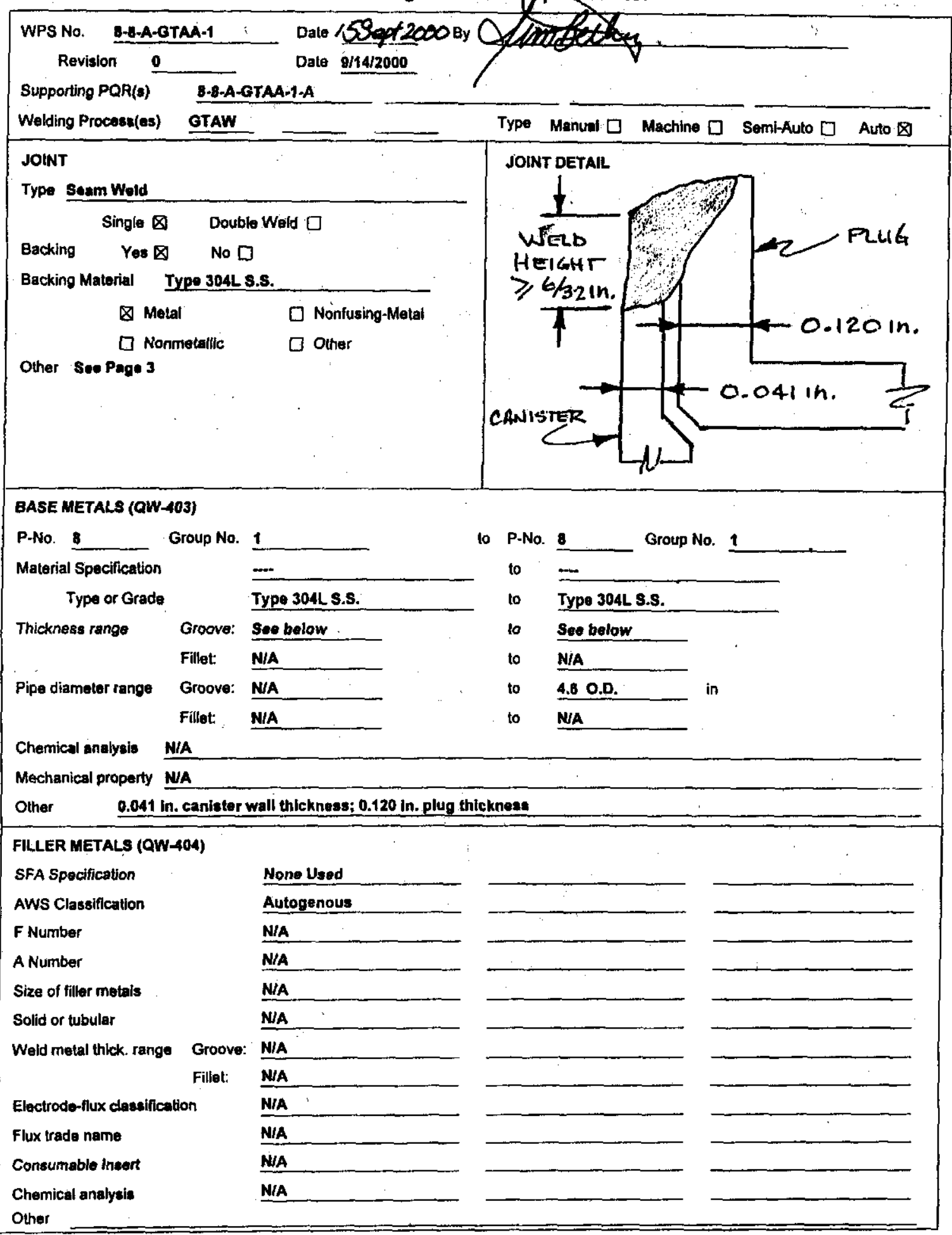




\section{Fluor Hanford}

\section{Welding Procedure Speclfication}

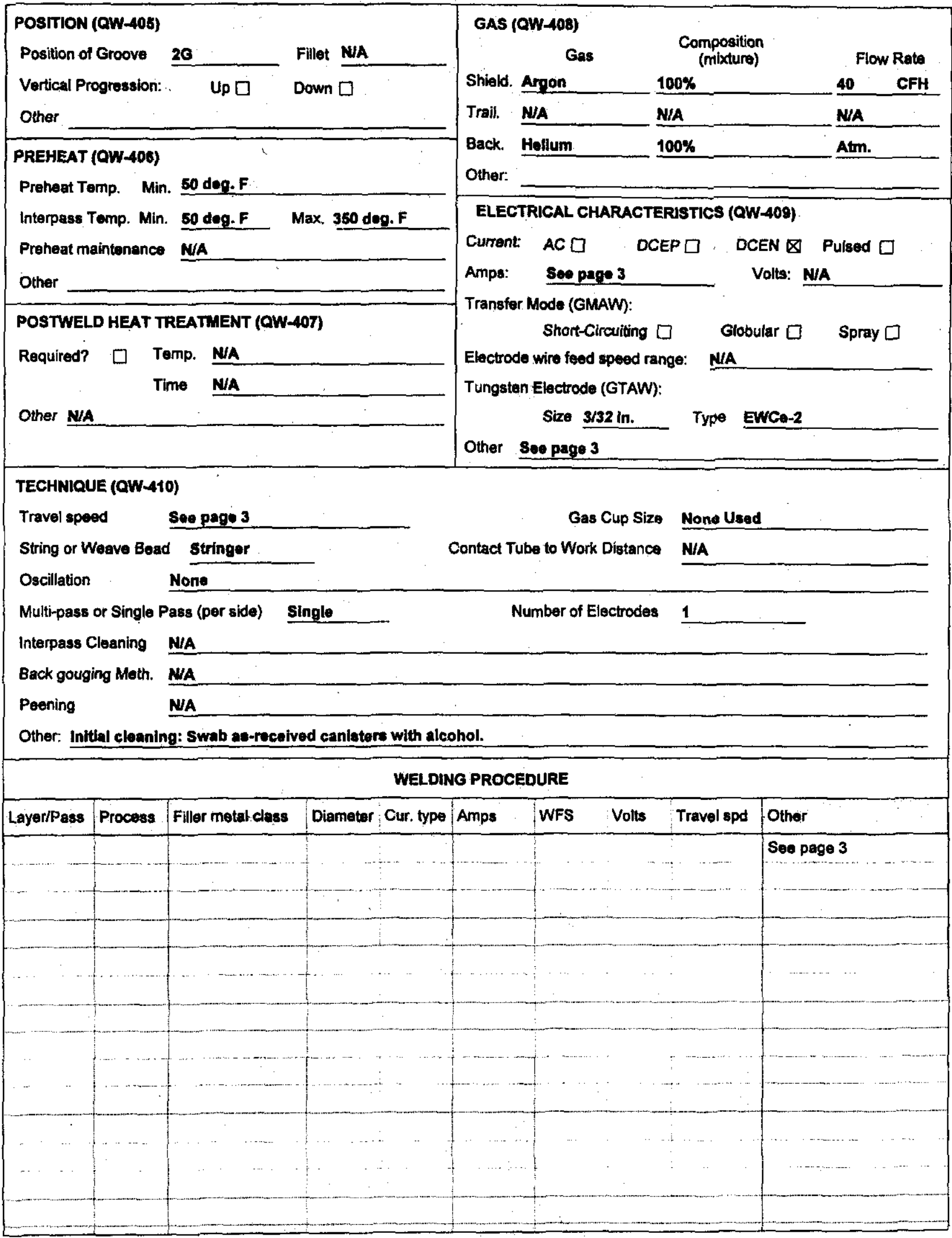




\section{Fluor Hanford \\ Welding Procedure Specification \\ 8-8-A-GTAA-1}

\section{Gas Tungsten Arc Welding Machine Settings for Arc Machine Model 227}

\section{Barameters}

\section{Settings Becommendations (Program 011)}

Welding Current (Pulsed)

Continuous welding

When making Tacks

Between Tacks

Pulse Rate (i.e., Cycle duration, sum of time for primary and background half cycle)

Continuous welding

Making Tacks

Between Tacks

Speed of torch motion

Continuous welding

Track welding

Between tacks

Initial Arc Gap

Gas Purge Rate before start of tacking

Electrode

Chemistry

Body diameter

Taper

Tip diameter

Shielding Gas

Tack Weld Geometry

Number/location

Size

Method of sharpening electrode tip

Orbital Head

\section{Banse of Parametere Oualified}

Canister to Plug Gap

Arc Gap (controlled by canister spec. \& length of special electrodes)

Primary Welding Current

\section{Nominal Settings/Values}

145 amps primary, 65 amps background 145 amps primary, 65 amps background 15 amps (no pulsing)

$0.6 \mathrm{sec}$. ( $0.4 \mathrm{sec}$. Primary, 0.2 background) $0.6 \mathrm{sec}$. (0.4 sec. Primary, 0.2 background) no pulsing

$0.62 \mathrm{rpm}$ (can dia. of $4.6 \mathrm{in}$.)

$0.62 \mathrm{rpm}$

$2.0 \mathrm{rpm}$

0.066 in.

$1.0 \mathrm{~min}$.

W $-2 \% \mathrm{Ce}$

$3 / 32$ in.

$24+/-1$ degree

pointed $0.015+/-0.005$ in. max. blunt

Argon, $40 \mathrm{CFH}$

3 (at $0,90,180$ degrees around canister Circumference). Continuous weld begins at 270 degreies.

approx. $0.9 \mathrm{in}$. long

automatic (Manual shaping of electrode tip is not allowed in production)

Arc Machine Model 9-7500

$0.002-0.008$ in.

$0.062-0.070$ in.

140 - 150 amps 